\title{
THE INFLUENCE OF BUBONIC PLAGUE IN ENGLAND 1500-1667
}

by

\author{
ALAN D. DYER*
}

A GOOD DEAL is now known about the incidence of plague in this country during the early modern period, but attempts to probe the wider impact of these epidemics on the general history of the era have been rare. This is curious, for plague occupies a prominent position in the historiography of the later middle ages; but while the disease remained a major factor in the lives of Englishmen for nearly two centuries after the close of the medieval period, the modern historian can find no place for it in his survey of the forces moulding the development of Tudor and Stuart England. This essay is an attempt to examine the demographic, social, economic, and moral impact of plague epidemics. It makes no attempt to cover the chronological and geographical patterns of the disease, or to describe its medical aspects, since these areas are well reviewed by recent published work. ${ }^{1}$

Of course plague was only one among many epidemic diseases which afflicted the period under examination: typhus and dysentery were more common, influenza (particularly in the great pandemic of 1556-59) killed many more people, and the rate of population growth continued to be determined by the many and obscure destroyers of children. Why, then, should we select plague for a special prominence? The answer lies in the uniquely disruptive and disturbing consequences of its epidemics, caused by certain basic characteristics of the disease which deserve prior treatment and are chiefly derived from the peculiar transmission of the organism by means of the rat flea.

A most important feature of plague was that it travelled slowly, and crossed open spaces with the greatest difficulty. This was due to the sedentary nature of the black rat, living whenever possible in the roof spaces of houses and averse to wandering across countryside or crossing water. For this reason plague was essentially a disease of towns, for only in such settlements was a concentration of houses, and so of rats, possible: the epizootic among rats which necessarily preceded a human epidemic required that infected rats or their fleas should be able to move easily between one house and the next, not commonly true of villages. When the disease was spread between communities, it was probably taken by infected rats or their fleas, carried involuntarily by carts, packhorses or ships, another factor concentrating infection on ports and towns on major roads. It is this necessarily urban concentration of plague *Alan D. Dyer, B.A., Ph.D., University College of North Wales, Bangor.

${ }^{1}$ E.g. Leonard F. Hirst, The conquest of plague, Oxford, Clarendon Press, 1953; John F. D. Shrewsbury, $A$ history of bubonic plague in the British Isles, Cambridge University Press, 1971; J.-N. Biraben, L'homme et la peste, 2 vols., Paris, Mouton, 1975-76; The plague reconsidered, Matlock, Derbyshire, Local Population Studies, 1977. 


\section{The influence of bubonic plague in England, 1500-1667}

which explains its limitations as a killer, since the majority of the population still lived in the countryside, but it also accounts for its economic influence, since towns were clearly crucial to the commercial life of the nation. Epidemics were chiefly confined to the warmer months of the year, coming to a peak between July and September; this reflected the temperature requirements of the flea, but its effect was to concentrate epidemics in the season of maximum activity in the pre-industrial economy, which displayed a marked annual rhythm. It also helped to prolong outbreaks over two or even more years, punctuated by winter respites.

If we are to appreciate the effect of these epidemics it is essential to appreciate the slowness of their spreading within the afflicted community, a movement which could well be of the order of a hundred yards per week or even less: this is surely a phenomenon unique to plague and accounts for much of its impact. It is derived from the aversion of the rats to movement, but it guaranteed both a maximum nervous tension and a virtual certainty of escape by flight, aspects to which we shall return. The disease was also a familiar one, since its symptoms were distinctive and notorious after centuries of outbreaks in Europe: at the beginning of the 1665 London epidemic "they terrified each other with remembrances of a former pestilence". ${ }^{2}$ This element of panic, leading to flight for those able to afford it and hysteria in those left behind, was heightened by the rapidity with which death followed infection and the very high mortality rate among sufferers, rarely less than fifty per cent. A sermon of $c$. 1600 speaks of the disease as "manifestly different from all other diseases, not only for the speediness thereof in death, but also for the outrage thereof in those that feel the same". ${ }^{3}$

Two other aspects of plague deserve special attention. The first is that it was distinctively a disease of the poorer classes-indeed it became known as "the poor's plague". Modern studies confirm this impression, revealing very few upper-class victims indeed. This may be explained in part by the withdrawal of the rich to the countryside at the beginning of epidemics, but must largely be due to the nature of the buildings inhabited by different social groups, for well-maintained houses with tiled roofs would harbour far fewer rats than the ramshackle huts of the poor. The truth of this is well illustrated by the 1665 London plague, when most of the city's aldermen and suburb's justices stayed at their posts - yet none died. ${ }^{4}$ The second aspect is that plague is essentially a disease of the household, a characteristic again derived from rodent infestation of the family home. Once the rats of a particular house were infected, it was likely that most, if not all, of its human inhabitants would develop the disease. Thus the mortality pattern of plague reflects the structure of contemporary lower-class households, with no particularly pronounced preference for young or old, male or female, which is independent of this factor. Most of the characteristics of plague which have been emphasized here contrast in a more or less marked way with the attributes of the other epidemic disease of the period, and taken together they do much to explain the uniquely disruptive and disturbing role which plague played.

2 Nathaniel Hodges, Loimologia, London, 1720, p. 3.

Bodleian Library, Oxford, Ms. Gough Eccl. Top. 7.

- Walter G. Bell, The great plague in London in 1665, London, John Lane, 1924, pp. 312-313. 
The demographic influence of bubonic plague is the most obvious yet least important of its major aspects. At the time of the last major epidemic in 1665-66, it is unlikely that more than twenty per cent of the population lived in settlements sufficiently urbanized to present a high risk of infection, and this modest figure itself represents a substantial increase on the sixteenth-century level. ${ }^{5}$ It is obvious from this fact alone that plague could not have been a crucial factor in determining the course of population change on a national scale. Its influence lay rather in the effect it had on the development of individual towns, and on the demographic structure of all towns. In assessing this influence one must distinguish sharply between the frequent minor outbreaks and the rarer major ones, for though the lesser incidents caused much disruption, they often caused no more than ten or twenty deaths. Maidstone, for instance, has records of plague deaths in twenty-four of the 106 years between 1562 and 1667 , but only six of them at most could be classed as serious. ${ }^{6}$

Thus it is with the major outbreaks that we are concerned: as a general rule, the larger the city, the more often it was infected. London, with a population far greater than any provincial city, was hit by nine major epidemics during the period we are considering, while the main provincial cities suffered on about six occasions, like Norwich (1578-79, 1583, 1591, 1603, 1625-26 and 1665-66). ${ }^{7}$ Smaller towns were struck twice on average during the period - Chester in 1603-6 and 1647-48, Lichfield in 1593 and 1645-46, and Leicester in 1593-94 and 1610-11, for instance. ${ }^{8}$ Often the proportion of the population killed in these rarer outbreaks was higher than in the bigger towns. The interval between major epidemics could be as short as five or six years, but was more commonly ten or twenty years and could sometimes be much longer; London escaped for twenty-nine years before 1665, York was similarly fortunate for over forty years before 1604, and Worcester until 1609. ${ }^{\circ}$ Such long remissions were unusual and the terminating epidemic was often marked by especial virulence, caused by overcrowded housing and the lack of that partial immunity which regular exposure to mild strains of the disease seems to have encouraged. It will readily appear from the foregoing that plague did not appear in most cities with sufficient frequency to act as a major restriction to population growth, and that in many places it was possible for a generation to mature between major outbreaks. This is, however, less true of the larger cities and least true of London and its surroundings.

How many people did the major epidemics kill? Here there is a temptation to dismiss the higher totals as the exaggerations of an unstatistical age, but there is in fact

\footnotetext{
5 Penelope Corfield, 'Urban development in England and Wales in the sixteenth and seventeenth centuries', in Donald C. Coleman and Arthur H. John (editors), Trade, government and economy in pre-industrial England, London, Weidenfeld \& Nicolson, 1976.

- J. M. Russell, History of Maidstone, Maidstone, 1881, pp. 224-233.

' Francis Blomefield, Norfolk, 2nd ed., London, 1806, vol. 3, p. 376.

- Anthony M. Johnson, 'Some aspects of the political, constitutional, social and economic history of the city of Chester 1555-1662', Oxford D.Phil. thesis, 1970, pp. 215-220; David Palliser, 'Dearth and disease in Staffordshire 1540-1670' in Charles W. Chalklin, and Michael A. Havinden (editors), Rural change and urban growth 1500-1800, London, Longmans, 1974, pp. 60-65; J. E. O. Wilshere, 'Plague in Leicester 1558-1665', in Trans. Leics. Arch. Soc., 1968-69, 44.

- The London outbreak of 1648, though significant, cannot be ranked with the major plagues of the capital. David Palliser, 'Epidemics in Tudor York', Northern History, 1973, 8: 52-53; Alan D. Dyer, The city of Worcester in the sixteenth century, Leicester University Press, 1973, pp. $21,45$.
} 
ample evidence that most totals are, if anything, mild underestimates. Parish registers can be used to check allegations, but in any case every practical consideration encouraged concealment rather than the overestimating of plague deaths. In southern France and Italy mortality rates frequently exceeded forty per cent of the pre-plague population of the affected city, and in some cases might pass the seventy per cent level, ${ }^{10}$ but in cooler England only a very few instances lie between forty and fifty per cent. The most conspicuous are the six thousand dead at Newcastle in 1635-36, two thousand at Chester in 1647-48, and the outbreaks in Carlisle (1598), Lichfield (1593), and Colchester (1665-66) ${ }^{11}$ It will be noted here that only Newcastle in this list could be considered a major city, and that the capital does not appear at all. However the larger cities do appear in the next ranks: outbreaks causing mortalities of thirty to forty per cent include York in 1604, and Southampton in 1664-65. ${ }^{12}$ The twenty to twenty-five per cent level was reached in Norwich in 1578-79, when nearly five thousand died, and in Bristol in both 1603-5 and 1645; probably London's worst plague, that of 1563 , should appear here, though all other outbreaks in the capital should be relegated to the relatively large class which killed between ten and twenty per cent of the pre-plague population. ${ }^{13}$ So although the most serious plagues were undoubtedly killers on a large scale, the towns afflicted in this way were very few, and most places lost perhaps on average about ten per cent of their population on each of two occasions spread over two centuries, although some of the larger, and a few of the smaller towns were hit either more frequently or more seriously.

What permanent effect did this have on town populations? Town records usually fail to show any direct evidence of gaps or problems which the sudden removal of a significant proportion of the citizens might be expected to cause. Instead one is struck by the speed and insidiousness of the rural migration which made good the deficiencies in a very short time. One authority claims the losses of the 1665 London epidemic were "after [a] few months ... . hardly discernible", 14 while Sir William Petty states of London: "let the mortality be what it will, the city repairs its loss of

$10 \mathrm{~J}$. -N. Biraben, 'Certain characteristics of the plague epidemic in France 1720-1722', in David V. Glass and R. Revelle (editors), Population and social change, London, Edward Arnold, 1972; Carlo M. Cipolla, Cristofano and the plague, London, Collins, 1973.

${ }_{11}$ Roger Howell, Newcastle-upon-Tyne and the puritan revolution, Oxford, Clarendon Press, 1967, pp. 2, 7-9; Rupert H. Morris, The siege of Chester, Chester, Chester and North Wales Archaeological Society, 1923, pp. 210, 242-243; William Whellan, History and topography of the counties of Cumberland and Westmorland, Pontefract, 1860, p. 92; Harry Thorpe, 'Lichfield: a study of its growth and function', in Staffs. Record. Soc. Colls., 1950-51, p. 66; I. G. Doolittle, 'The effects of the plague on a provincial town in the sixteenth and seventeenth centuries', Med. Hist., 1975, 19: 333-341.

12 Palliser, op. cit., note 9 above, p. 54; Alfred T. Patterson, History of Southampton, Southampton University Press, 1966, p. $2,6$.

13 Blomefield, op. cit., note 7 above, vol. 3, pp. 354, 360; William Hudson and J. C. Tingey (editors), Records of the city of Norwich, Norwich, 1906, vol. 2, pp. cxxvii-viii; Samuel Seyer, Memoirs historical and topographical of Bristol, Bristol 1823, vol. 2, pp. 259, 430, 466; John Evans, Chronological outline of the history of Bristol, 1824, p. 165; Shrewsbury, op. cit., note 1 above, p. 487; all London epidemic death rates are less certain than those of provincial towns because of the sheer scale of the problem, and difficulties over the size of the pre-plague population and the exact area covered by the mortality statistics.

14 Hodges, op. cit., note 2 above, p. 28. 
inhabitants within two years".15 This conclusion was reached on the basis of the rapid recovery of baptismal totals to pre-plague levels, but must be over-optimistic since the beightened marriage rate in the aftermath of epidemics led to an artificially raised birth-rate for several years. But a rapid influx of migrants is indicated at Colchester, where a mortality of about fifty per cent in 1665-66 had been replaced to such an extent that in March 1666 only 279 houses lay empty, about thirteen per cent of the total. ${ }^{16}$ Gaps among the self-employed naturally took longer to replace (for few rural migrants would have possessed either capital or qualifications for immediately setting up in business) so we find the freemen's records of many towns showing a raised level of recruitment for four or five years after major epidemics - in York for instance the annual average of forty-five new freemen immediately before the great plague of 1604 is followed by totals of about eighty for each of the four subsequent years. ${ }^{17}$ Some temporary reduction in the numbers receiving poor relief has been noted in Salisbury and Norwich, but even this effect disappears within a few years. ${ }^{18}$

So it would appear that epidemics had no long-term influence on town population levels and that damage was quickly and effortlessly made good. Although this generalization does seem to be consistent with the experience of many towns, it should not be regarded as of universal application. The crucial factor was the presence in the countryside of a population surplus, ready and willing to flock to the towns to replace epidemic losses. But when there was no surplus, or that surplus could not be lured into particular depopulated towns, the situation changed. The problem rarely arose in the period roughly $1560-1640$ since the rural population seems then to have been growing with notable vigour, so the only towns which experienced any difficulty were those which were too depressed to attract poor migrants. A good example here is York, which complained of depopulation after its mid-sixteenth-century epidemics. ${ }^{19}$ Such situations were not common, but far more frequent were the problems of towns hit hard by the plagues of the period 1642-1667, when there seems to have been a much smaller population surplus in the countryside, quite probably no surplus at all in some regions. Here we find many more examples of towns taking decades to replace their epidemic losses when their economy is not strong, and half a century or more when the economy concerned is positively weak. Among larger towns Southampton provides us with an example of a town incapable for the remainder of the seventeenth century of replacing the heavy losses of the plague of 1666, while among recently studied smaller towns, Ashby-de-la-Zouch and Stafford both suffer decades of population stagnation after their epidemics of the $1640 \mathrm{~s}^{20}$ It seems gener-

${ }^{15}$ Charles H. Hull (editor), Economic writings of Sir William Petty, Cambridge, 1899, vol. 2 , p. 368.

${ }^{16}$ Doolittle, op. cit., note 11 above, p. 334.

17 Palliser, op. cit., note 9 above, p. 57.

18 Paul Slack, 'Poverty and politics in Salisbury 1597-1666' in Peter Clark and Paul Slack (editors), Crisis and order in English towns 1500-1700, London, Routledge, 1972, p. 170; Hudson and Tingey, op. cit., note 13 above, vol. 2, p.cv.

10 Yorkshire Archaeological Society, York civic records, 1946, 5: pp. 97-98, 1950, 7: p. 33.

${ }^{20}$ Patterson, op. cit., note 12 above, pp. 2, 6; C. J. M. Moxon, 'Ashby-de-la-Zouch-a social and economic survey 1570-1720', Oxford D.Phil. thesis, 1971, pp. 40-42; Kenneth R. Adey, 'Seventeenth century Stafford', Midland History, 1974, 2: pp. 156, 162. 


\section{The influence of bubonic plague in England, 1500-1667}

ally true that this decade forms a demographic turning-point for the whole of the seventeenth century for many towns, and probably for the whole country, and this effect was intensified very greatly if, as was often the case, a major epidemic coincided with this crucial phase. However the significance of this aspect of plague is somewhat reduced by its restriction to a single generation by the disappearance of the disease after 1667.

Plague has another aspect to its demographic influence in its effect on the structure, as opposed to the size, of urban populations. Most killer diseases of the period struck principally at children, leaving the basic adult social structure relatively unscathed and parents free to replace lost children as far as possible. In contrast, plague seems to have affected all age groups and sexes roughly in proportion to their distribution within the infected community, although there does seem to have been a rather heavier mortality among men, and young adults in general. ${ }^{21}$ Presumably these minor variations depended on the likelihood of being bitten by a flea and to some extent on previous exposure to the disease. But much of this must remain speculative since our ignorance of the basic demographic characteristics of the population at risk renders attempts to construct specific mortality rates largely futile.

We can, however, be fairly sure that these epidemics did play a part in shaping the particular demographic structure of pre-industrial society. They injected into this structure certain irregularities which lasted as long as the generations concerned: in the rare and invaluable statistical survey of the city of Lichfield prepared by Gregory King in 1695, there is a general lack of balance in the distribution of the sexes and age cohorts, most pronounced in the lack of people aged between fifty and fifty-five: this must surely have been caused by the loss of most of the children born between 1640 and 1645 in the great plague of $1645-46 .{ }^{22}$ It is notable here that though young children were not unusually susceptible to the disease, their loss was never replaced, unlike older age groups which were replaced by migrants of roughly the same age. Since plague killed a higher proportion of adults than most other diseases, and especially more men, it disrupted the nuclear family far more, for not only was the family the basic economic as well as social unit, but families were far better prepared to weather the loss of women than men. In any case the disruption of marriages prevented the immediate replacement of dead children and increased the already high proportion of orphans.

Thus although plague's influence over the demographic development of this country was a significant one, this aspect of the disease has been subject to considerable exaggeration. Far more significant is the role of plague as a destructive and disruptive force in the broader life of the community. In human reactions to the threat of plague lies the key to an understanding of this disruptive power. This aspect may be considered under two heads, first, the response of organized authority and

21 A. B. Appleby, 'Disease or famine? Mortality in Cumberland and Westmorland 1580-1640', Econ. Hist. Rev., 2nd series, 1973, 26: p. 407n; R. Welford, History of Newcastle and Gateshead, London, 1884, vol. 3, pp. 56-57; M. F. Hollingsworth and T. H. Hollingsworth, 'Plague mortality rates by age and sex in the parish of St. Botolph's without Bishopsgate, London 1603', in Population Studies, 1971, 25.

22 D. V. Glass, 'Gregory King and the population of England and Wales at the end of the seventeenth century', Eugenics Rev., 1946, fig. 2, table 5. 


\section{Alan D. Dyer}

second, that of the individual. Local government acted with one principal weapon isolation. All members of infected households, sick and well, were immediately confined in their homes for many weeks. More drastic measures included the nailing up of doors and the fencing off of infected streets with palings and watchmen. By the seventeenth century it became normal for the sick to be transferred to temporary isolation hospitals - pesthouses - in the suburban fields, leaving the contacts in domestic quarantine. In extreme cases both sick and well were removed to the pesthouse; Bristol did this in 1644-45 but it was both expensive and deeply resented by the contacts. ${ }^{23}$

A broader measure of isolation was the cutting off of contact between entire communities and their neighbours. Infected towns prevented their citizens spilling into the countryside to spread the disease, though this was usually only done at a late stage of the epidemic; with much greater enthusiasm healthy towns in infected regions turned away travellers and goods from suspect localities. These precautions seem to have become much more elaborate from the early seventeenth century onwards, and the result of this programme of communal isolation was that in bad years there was a virtual breakdown of all forms of communication. The diarist John Evelyn travelled thirty-five miles through the Home Counties during the widespread plague of 1625 , and one of the salient memories of his youth remained "the strict watches and examinations upon the ways as we passed". ${ }^{24}$ One Worcestershire constable explains that he has not apprehended his usual tally of vagrants because "there are very few that walk". ${ }^{25}$

If isolation was the reaction of authority, the response of the individual was equally simple: flight. The slow spread and urban location of plague meant that evacuation, even over quite short distances, was a natural and effective precaution. The migration was rapid, and took place at the beginning of the epidemic, before effective measures could be taken against it, or the countryside learned to shun the townsman. At the beginning of the Salisbury plague of 1627 we are told that everyone with friends in the country "did fly as if it were out of an house on fire", most of the wealthy having left in four days. ${ }^{26}$ The best documented evacuation is that of Norwich in 1665 , which was largely completed during the two weeks following a marked rise in the plague death rate in early July. ${ }^{27}$ These migrations, which should be regarded as a standard feature of nearly all serious epidemics, were fatal in themselves to the continuance of any sort of normal life within the towns concerned; the class which could afford to leave was also the one which monopolized the personnel of local government and owned most larger business concerns. The result of its withdrawal could only be the collapse of both the local economy and municipal administration.

Here we are tempted to suspect that "collapse" is too strong a word to describe the situation, yet a wealth of contemporary description confirms its validity. We are told that the only civic officials left in Salisbury were the mayor and two petty constables, and that the flight in Exeter closed most of its businesses and brought its

${ }^{23}$ H. E. Nott (editor), Deposition books of Bristol, Bristol Rec. Soc., 1935, 1 : p. 16.

${ }^{24}$ Diary and correspondence of John Evelyn, London, 1857, vol. 1, p. 5.

${ }^{25}$ Historical Manuscripts Commission, Various collections, 1901, 1: p. 314.

${ }^{26}$ Slack, op. cit., note 18 above, p. 172.

${ }^{27}$ Calendar of State Papers Domestic 1665-66, pp. 513, 523, 542, 551, 568; 1666-67, pp. 393-394 


\section{The influence of bubonic plague in England, 1500-1667}

administration to a halt. ${ }^{28}$ In Great Yarmouth "the poor are deprived of the charity and trade of the inhabitants, who are fled, so that it is like a country village", while in Chester "almost all persons of ability have left the said city, there remaining for the most part only the poor, who are altogether deprived of trading". ${ }^{29}$

A significant aspect of these migrations is that they are much more typical of the seventeenth than the sixteenth century. In Exeter 1503 saw two bailiffs and two mayors die at their posts in succession, and in 1537 four members of the corporation died, yet in 1570 we are told that the "chiefest men" left the city and in 1625 the whole upper class fled, leaving behind one of the worst administrative and economic collapses on record. ${ }^{30}$ The great Elizabethan plagues seem to have taken their toll of city rulers who stayed at their posts, and economic damage was caused by isolation rather than the closing down of businesses consequent upon their owners' departure - thus both the Bristol and Norwich epidemics of the reign took the lives of several aldermen. ${ }^{31}$ Yet in the seventeenth century we rarely hear of the death of any leading townsman, and the typical example becomes that set by Samuel Newton, alderman of Cambridge, whose diary records the fact that he spent the months between June and October of 1665 with his family at Waterbeach, some six miles from the infected town.32

We should not exaggerate the extent of this trend, for there did exist panic flights in the sixteenth century and prominent examples, like those of York in 1631 and London in 1665, of administrations which remained at their posts; however even here the wealthier traders without civic responsibilities still left. ${ }^{33}$ The phenomenon remains a significant one, and points to a dwindling sense of civic-mindedness and a disintegrating awareness of communal bonds and loyalties. It is easy to censure the refugees, yet those who did stay behind often suffered grievously for their sense of duty: a Ludlow petty official claims that "he was not only in danger of his life but [also those] of his wife and children and his house shut up for a season and lost his customers and his work and his servants departed from him."34 Towns did sometimes try to force officials to stay by fining absentees, and occasionally extended the measure to include all citizens, but such acts could only be effective in minor outbreaks, and Norwich was more realistic in ordering petty officials to return only if they had omitted to appoint a deputy. ${ }^{35}$

The collapse of administration and commerce are but two examples of the cessation of most kinds of public activity. Schools were disbanded at the first sign of danger -

${ }^{28}$ Slack, op. cit., note 18 above, p. 172; William B. Stephens, Seventeenth century Exeter, Exeter University Press, 1958, pp. 13-14.

${ }^{29}$ 'The great plague in Yarmouth' in Notes and Queries, 1957, 202: p. 109; Johnson, op. cit., note 8 above, p. 322.

${ }^{30}$ Ransom Pickard, Population and epidemics of Exeter in pre-census times, Exeter, James Townsend, 1947, pp. 29-33, 36-37; Walter J. Harte, Gleanings from the common-place book of John Hooker, Exeter, A. Wheaton, 1926, pp. 8, 31; Stephens, op. cit., note 28 above, pp. 13-14.

31 Blomefield, op. cit., note 7 above, vol 3, p. 354; Seyer, op. cit., note 13 above, vol. 2, p. 246.

32 J. E. Foster (editor), Diary of Samuel Newton of Cambridge 1662-1717, Cambridge Antiquarian Soc., Octavo Publications, 1890, vol. 23.

${ }^{23}$ B. M. Wilson, 'The corporation of York 1580-1660', York M.Phil. thesis, 1967, p. 177.

34 Shropshire Record Office, Ludlow corporation records, "bailiff's etc. accounts", 1608-9.

${ }^{35}$ Walter Rye (editor), Notes from two court books of the city of Norwich 1666-1685, Norwich, 1905 , p. 118. 
in Norwich they closed throughout the summers of 1590 and 1592, neither of them particularly serious epidemics. ${ }^{36}$ Oxford and Cambridge terms were subject to constant dislocation, some of the colleges maintaining refuges for their members in neighbouring villages. Church services were often abandoned and civic ceremonial cancelled, while meetings of assize and quarter session courts were transferred to healthier locations, a serious blow to the towns concerned. Markets and fairs were the first casualties of serious epidemics. The result of all this was that towns lost their familiar signs of life - "by report there is scarce a man to be seen in the streets". 37 The classic detail is that grass grew in the streets, perfectly feasible when they were roughly paved and well fertilized. The Chester chronicle sums up this aspect well: "this year the government passed without any matter of importance by reason of the plague increasing among us"..$^{38}$

This urban paralysis created a desperate need for relief among those isolated in towns whose economies had collapsed. Here the medical aspect of the epidemic is dwarfed by the needs of those who were healthy but impoverished. Some figures will illustrate this fact: the 1637 plague in Bury St. Edmunds had at one stage 107 people ill, 103 families in domestic quarantine but about 4,000 people unable to survive without massive public assistance to the tune of $£ 200$ per week. ${ }^{39}$ Cambridge struggled to support 4,000 people in an epidemic which cost only 400 lives, while the relatively minor outbreak in Salisbury in 1627 had at one stage infected only twenty-seven houses but had thrown 2,674 people on to public charity. ${ }^{40}$ In the same city in 1666 the 154 people sick or in quarantine cost $£ 30$ per week but the 1,855 poor needed $£ 108$ weekly. 11

Thus an epidemic whose cost in lives could be relatively modest could impoverish the majority of the surviving population, causing problems of unemployment, hunger, and public finance which were unprecedented in the experience of the local authorities concerned. Relief was usually dispensed as a small weekly dole, sufficient to avoid starvation, and when food supplies failed with the collapse of markets, provisions were supplied in bulk too. In the absence of any organization specifically designed to meet such an emergency, the burden on town governments and rural justices was a heavy one: the Bury plague of 1637 cost over $£ 2,000$, at Preston $£ 856$ was spent in fifteen weeks, the minor Salisbury outbreak of $1604-5$ cost the corporation £589, and Norwich spent over $£ 8,000$ in $1665-66 .^{42}$ It is difficult for those unfamiliar with contemporary financial values to appreciate the relatively vast size of these sums, usually greater than the normal total annual expenditure of the towns concerned, and representing a far heavier burden on the taxpayer than all other regular forms of taxation - further impoverishing the community at a time of economic difficulty.

36 Hudson and Tingey, op. cit., note 13 above, vol. 2, pp. 195-196.

37 Hist. Mss. Comm., Sixth Report, appendix, p. 329.

s8 Cheshire Sheaf, 1935, item 6651 (1603).

39 Samuel Tymms (editor), Wills and inventories from Bury St. Edmunds, Camden Soc., 1st series, 1850, vol. 49, p. 263.

${ }^{40}$ Charles H. Cooper, Annals of Cambridge, Cambridge, 1842-1900, vol. 3, pp. 227-228, 239; Slack, op. cit., note 18 above, p. 172.

11 Hist. Mss. Comm. Various Collections, vol. 1, p. 148.

12 Tymms, op. cit., note 39 above, p. 263; Hist. Mss. Comm., Fourteenth report, Appx. iv, pp. 45-46; Slack, op. cit., note 18 above, pp. 169-170; Blomefield, op. cit., note 13 above, vol. 3, p. 410. 
The ultimate cause of these difficulties was the failure of local commerce, a topic of great importance. The commonest single symptom of this damage was the suspension of fairs and markets, a detail easy to pass over without full appreciation of its significance. Towns relied on their markets as their chief source of food, raw materials and customers for their shops and stalls, while fairs were vital for the organization of inter-regional trade. Once an epidemic was established both these commercial gatherings quickly petered out, through both official closure, due to the risk of spreading infection, and the natural reluctance of countryfolk to attend at the risk of their lives. ${ }^{43}$ These closures could last for up to six or nine months in many cases, and the resultant lack of both raw materials and buyers quickly closed down local businesses, even if they could survive the flight of their owners. Temporary markets were set up in suburban fields (many towns retain traditions of their location) but they were always very inadequate substitutes, since attendance at them demanded either desperation or eccentricity: one such market organized outside Norwich, the country's second city, in 1666 attracted only one solitary Quaker. ${ }^{44}$

The last major plague in 1665-66 was said to have been "an infinite interruption to the whole trade of the nation".45 In Exeter we are told of the "deadness of trade in these last years, more especially in the year of God's visitation, [1625] wherein was almost no trading". ${ }^{46}$ In Devon the vital textile industry, dependent on the frequent exchange of part-finished goods, could be depressed even by rumours of epidemics. ${ }^{47}$ A tract of 1643 refers to the plague ended seven years before in Newcastle: "thy trading departed, as thou never yet recovered it".48 These illustrations suggest that plague could have a very marked effect on urban economies, but they remain impressions, often derived from prejudiced sources.

The problem of testing the validity of such pronouncements is that reliable statistical series which might be used to measure the economic performance of individual towns are rare, and always difficult to interpret. The best source is provided by government regulation of the cloth industry. Figures for the export of shortcloths from London indicate that they fell by about twenty-five per cent in the plague year of 1603 , but this would be distorted by the diversion of trade to other ports. ${ }^{49}$ Reduced levels of cloth production are indicated in Norwich, where the cloths produced by the alien community fell by about twenty-five per cent in number in 1578: this is a surprisingly modest reduction considering the severity of the epidemic, but it is probable that the alien community found migration to the countryside far more difficult than the native one, so that clothmaking continued at a modest level throughout the plague..$^{50}$ More substantial damage is indicated at Colchester, where the total

4s Markets were partly kept open in the capital, but the size of London, the means by which it was supplied and the reliance of suppliers in the Home Counties on the London market seem to have rendered it a separate case.

4 Cal. State Papers Domestic 1666-67, p. 53.

4s Ibid., 1664-65, p. 523.

4 Hist. Mss. Comm., Records of the city of Exeter, 1916, p. 109.

17 Thomas Westcote, $A$ view of Devonshire in MDCXXX, Exeter, 1845, p. 62.

$\triangle 8$ Welford, op. cit., note 21 above, vol. 3, p. 338.

- Barry E. Supple, Commercial crisis and change in England 1600-1642, Cambridge University Press, 1959, pp. 25-26.

${ }^{50} \mathrm{~K}$. J. Allison, 'The Norfolk worsted industry in the sixteenth and seventeenth centuries', Yorks. Bull., 1961, 13: p. 67. 


\section{Alan D. Dyer}

number of cloths woven by the English producers is reduced by two-thirds in 1666 and one-third in the following year. ${ }^{51}$ Figures derived from the toll revenues of markets indicate a broadly similar scale of damage - these are necessarily derived from minor epidemics since markets closed in major ones, but in Reading the market toll income was halved for thirty-seven weeks, and in Beverley, which was not itself infected although its region was, the income from the wool market was reduced from $£ 46$ to $£ 36$ in 1665 , indicating the general depression which afflicted the hinterlands of towns in these circumstances. ${ }^{52}$

The slight Chester plague of 1604 led to a distinct recession in the city which is reflected in the records of the shoemakers' company. ${ }^{53}$ The number of adult wageearners employed in the city's shoemaking businesses dropped from a level of fiftytwo to fifty-four in previous years to forty-one in the plague year, recovering to fifty-nine in the following year: the epidemic seems chiefly to have forced larger undertakings to cut their workforces. Mortality among employees could also cause dislocation, for the newly-established Newcastle glass industry lost so many of its skilled workmen in 1636 that production was still held back late in the following year. ${ }^{54}$ Some final figures from the corporation accounts of Oswestry after its severe epidemic of 1559 reveal the chaos produced among the tenants of corporation properties. ${ }^{55}$ Three of the five tanners have left the town; of the nine glovers, one is dead, two are too poor to pay their rent, and two have fled; seven of the sixteen butchers have left, and three more are dead, while three of the five leather-workers have left. Here the damage is caused primarily by flight rather than death, probably always true of the self-employed class to which these figures relate.

Once an epidemic was over, normality in industrial and commercial life seems to have been restored with remarkable speed. Temporary trading patterns were usually abandoned again, although some towns had to fight to restore their rights - York, for instance, threatened to fine those of its merchants who had transferred their businesses to nearby country towns and were tardy in returning to the city. ${ }^{56}$ Recorded instances of this kind are relatively uncommon. Complaints that plague caused the permanent decline of particular towns are rather more frequent, though none is at all easy to substantiate. There is circumstantial evidence that some towns - York and Southampton are good examples - found recovery from plague damage far more difficult than did more prosperous places. All examples feature towns which were economically weak before the epidemic, which came to accelerate an inevitable decline: this is not to deny the part played by the disease in damaging the economies concerned, but rather to suggest that it acted as a precipitant of decline rather than a primary cause.

S1 Doolittle, op. cit., note 11 above.

52 J. M. Guilding, Reading records, London, 1896, vol. 3, p. 438; Beverley borough records 15751821, Yorks. Arch. Soc. Record Series, 1932, vol. 84, pp. 136-140.

${ }^{63}$ D. M. Woodward, 'The Chester leather industry', Trans. Hist. Soc. Lancs. Cheshire, 1967, pp. 96-97.

s4 Welford, op. cit., note 21 above, vol. 3, p. 352.

s5 Stanley Leighton, 'Records of the corporation of Oswestry', Shropshire Arch. Nat. Hist. Soc. Trans., 1880, 3: pp. 69-73.

se Joan Thirsk and J. P. Cooper (editors), Seventeenth century economic documents, Oxford, Clarendon Press, 1972, p. 328. 


\section{The influence of bubonic plague in England, 1500-1667}

Plague's economic influence was too general to be detectable in this specific fashion: sooner or later it was a basic fact of all urban life, so that its effect was to impoverish and weaken towns as a species. As we have seen, epidemics damaged healthy towns in an infected region, as well as the more obvious ones, so that we must see it as a general discouragement to sustained economic growth, periodically sapping the capital of the self-employed through the suspension of their business activities, and by making urban life unpleasant and insecure, encouraging the investment of surplus capital in rural properties rather than urban trade and industry. Thus it must be added to the long list of other factors which delayed until the industrial revolution the achievement of sustained economic growth.

The impact of plague upon the societies which experienced it is another topic of major significance. The most common effect was the encouragement of social conflict, that fragmentation of previously cohesive urban societies which took place in the seventeenth and eighteenth centuries. The quarantine system was the object of a very natural resentment, intensified by the bitterness induced by the escape of the rich. When trying to remove infected people to the pesthouse, the mayor of Salisbury was asked "whether I came of a woman or a beast that I should do so bloody an act upon poor people in their condition". ${ }^{57}$ A Haverfordwest woman protests that quarantine treats her "worse than a whore". ${ }^{58}$ An explosive mixture was produced by the combination of the similarity of quarantine to imprisonment (suggesting an element of punishment) the breaking up of families by removal to the pesthouse, the injustice of the escape of the rich whom the authorities represented and the collapse of the economic and administrative structure, and all this in an atmosphere highly charged with nervous tension.

The result was often a partial revolt, with the threat of a far more serious uprising in the background. The quarantine system was widely resisted so that the "unruly infected" in Norwich obliged the city to appoint special prisons in 1631, and in 1666 to provide whipping post and stocks at the pesthouse. ${ }^{59}$ "The unruliness of the infected persons and want of government" were apparent in Manchester in $1631^{60}$ despite a statute of 1603 which reinforced the powers of the authorities in dealing with breaches of quarantine by prescribing heavier penalties, including death. ${ }^{61}$ Leicester reacted by instructing its watchmen to open fire with crossbows on offenders. ${ }^{62}$ A more general threat to stability came from the deep resentment caused by the flight of the rich, which threw the poor out of work, deprived local government of its tax revenue, and weakened its ability to exert authority. In Exeter the unemployed poor rioted, threatening to burn the city down if the rich did not return to

57 Slack, op. cit., note 18 above, p. 57.

${ }^{58}$ Bertie G. Charles (editor), Calendar of the records of the borough of Haverfordwest, Cardiff, University of Wales Press, 1967, p. 98.

6 W. L. Sachse (editor), Minutes of the Norwich court of mayorality 1630-31, Norfolk Rec. Soc., 1942, 15: p. 179; Rye, op. cit., note 35 above, p. 119.

${ }^{\circ}$ W. E. A. Axon (editor), 'Documents relating to the plague in Manchester in 1605', Chetham Miscellanies 3, Chetham Soc., 1915, n.s. 73: pp. iv, 4-6.

'I I James I ch. 31, "An act for the charitable relief and ordering of persons infected with the plague".

'Shrewsbury, op. cit., note 1 above, p. 297. 
help them, ${ }^{63}$ while Salisbury's stern mayor John Ivie was faced with mobs roaming the streets demanding relief and threats to loot the homes of the absent rich. ${ }^{64}$ On reflection he considered plague to be God's judgment on that "great, unjust, rude rabble". ${ }^{65}$ The poor resented his authoritarian and puritan rule to such an extent that they became aligned with religious and political conservatism in the disputes leading up to the civil war. ${ }^{66}$ Although these epidemic antagonisms rarely reached the point of actual violence, the risk of it remained a constant pre-occupation of town governments: the mayor of York worries that "the poorer sort will not be ruled", while the town clerk of Norwich writes that "we are in greater fear of the poor than of the plague, all our money being gone".67

The most disturbing tensions were probably those set up between individuals, as fear of infection ate away at all social connexions. A plague sermon refers to this strain of avoiding contact - "daily devices amongst ourselves, how to avoid and escape dangers". ${ }^{68}$ The situation led to the abandonment of the deepest instincts of sociability, a profoundly disturbing development when mutual assistance and comfort from relatives, friends, and neighbours was the chief source of security in a hazardous world. A Bury man refers to his difficulties when "I could get nobody to help me and that all my household fled from me and left me comfortless (in respect that at that time my man died of the sickness) when myself and my wife were both lame".69 Cupper's sermons refer to this: "a man's dearest friends and kinsfolks forsake him. Many that are sick of this disease have none at all to attend them or visit them, and so they die without any looking to and without any physician for body or soul." 70 Hodges refers to the state of those shut up in domestic quarantine, "the consternation of those thus separated from all society", and attributes their frequent deaths to the low state of their morale. ${ }^{71}$ This erosion of the powerful bonds which held together pre-industrial communities must have left an indelible mark on those who experienced it, perhaps too deep to write about; only Samuel Pepys bared his soul to his diary in admitting that plague was "making us cruel as dogs one to another". 72

Epidemics also affected the established relationship between country and town. Townsmen were shunned, and could only find refuge if they had some prior rural connexion. Londoners were particularly subject to this antagonism, but differences in dress between countryfolk and the citizens of the larger towns made the identification of refugees so simple that it could be a general occurrence - Worcester

as Stephens, op. cit., note 28 above, pp. 13-14.

a John Ivie, A declaration. . . ., London 1661.

es Ibid., p. 19.

co Paul Slack, 'Religion, protest and urban authority: the case of Henry Sherfield, iconoclast, 1633' in Studies in Church History, Cambridge, 1972, vol. 9, p. 301.

"7 Palliser, op. cit., note 9 above, p. 61; Robert H. Hill (editor), Correspondence of Thomas Corie, Norfolk Rec. Soc., 1956, 27: p. 20.

'8 E. M. Wilson, 'Richard Leake's plague sermons 1599', Trans. Cumberland and Westmorland Antiq. and Arch. Soc., 1975, 75: p. 155.

60 Tymms, op. cit., note 39 above, pp. 172-173.

70 William Cupper, Certaine sermons concerning God's late visitation, London, 1592, p. 112.

71 Hodges, op. cit., note 2 above, pp. 7, 11.

12 Robert Latham and William Mathews (editors), Diary of Samuel Pepys, London, G. Bell, 1972, vol. 6, p. 212 
people for instance found that "the best was shunned, stoved off, turned back again". ${ }^{73}$ Further resentment was created by the failure of country people to contribute to the relief of infected towns in their neighbourhood. A statute of 1603 formalized a common arrangement by authorizing taxes on parishes within a fivemile radius of an infected town, extendible to ten miles or even a whole county. ${ }^{\text {" }}$ Yet these sums frequently proved almost impossible to collect - Norwich had exhausted its own money by 9 August 1666 and was awaiting the help of rural taxation, but as late as 10 October, when the emergency was almost over, no money had appeared and there were reports that most villages had produced derisory sums. ${ }^{75}$

Thus the effect of plague was to produce antagonisms between many established social groups, between family, neighbours, and friends, rich and poor, town and country. Probably the most significant casualty was the long-established relationship between rich and poor. The financial contrast between the two groups was a glaring one, yet both classes lived cheek-by-jowl in small and tightly knit communities; extended conflict is, however, rare before the seventeenth century. The system had always depended on paternalistic idealism from the upper class and passive deference from the lower one. The plague experience, and especially the flight of the rich, helped to erode this understanding, which was in any case in decline.

Besides weakening social cohesiveness, plague created a high degree of mobility, both social and geographical. Adult deaths created openings in the economic, social, and political hierarchy which were filled by those who would have been excluded by a more stable system; the effect was intensified by the way the unpleasantness and insecurity of town life encouraged the rich and successful to move to the countryside as soon as possible, leaving more opportunities behind them. Geographical mobility was increased by the influx of immigrants from the countryside which so quickly replaced epidemic losses. This certainly helped to strengthen the links between country and town - a quarter of the population of Norwich had been born outside the city according to a census of 1693 - but it also discouraged the development of a distinctly "urban" outlook and weakened the old sense of towns as clearly distinct capsules within their walls, in the countryside but not of it. ${ }^{76}$ The sudden removal of a substantial proportion of a town's population, to be replaced by strangers, tended to weaken the transmission of specifically urban traditions and customs, the rich inheritance from the middle ages of processions, drama, and festivals which was so gravely damaged during these years. Other forces - conspicuously protestantism - were at work here, but even the temporary cancellation of customary activities provided a pretext for their permanent abandonment.

The last broad aspect of plague to be considered is its mental and moral effect. A mere thirty years after the last epidemic Richard Baxter wrote, "It is scarce possible for people that live in a time of health and security to apprehend the dreadfulness of that pestilence". ${ }^{77}$ The survivors of epidemics had experienced a protracted period

78 Philip Tinker, Worcester's affliction, Worcester [c. 1780].

"7 S. J. Chadwick, 'Some papers relating to the plague in Yorkshire', Yorks. Archael. J., 18981900, 15: illustrates the administrative complexities.

75 Cal. State papers Dom. 1666-67, pp. 119, 141, 161, 191; Hill, op. cit., note 67 above, pp. 19-22.

76 J. K. Edwards, 'Norwich bills of mortality 1707-1830', Yorks. Bull., 1969, 21 : p. 108.

7 Reliquiae Baxterianae, London, 1696, vol. 3, p. 2. 


\section{Alan D. Dyer}

of nervous tension shot through with episodes of horror and grief. Dekker wrote of the disease as dreadful in three ways: "in the general spreading; in the quickness of the stroke; and in the terror that waits upon it."78 We might add to these the fact that there was no escape from the suffering of the victims-_"some drown themselves, others would kill themselves; they die within a few hours; some run up and down the streets in their shirts to the great horror of those in the city". ${ }^{79}$ Plague sermons stress the anguish of those forced to witness such incidents: "It terrifieth men, I say, when they see people die on every side of them, when they hear crying and groaning in every house round about them";80 "what sighing of the sick, what groans of the grieved, what wailing of widows, what crying of children, what howling of orphans and what woeful lamentations are there all night in every street!"81

Of course no-one living at this time could be a stranger to suffering and death, but that general familiarity could not anaesthetize them against the rigours of the plague epidemic. Ignorant of the true nature of the disease, desperate for an explanation which would make it all more bearable, people turned to the traditional religious interpretation of epidemic diseases. They were sent by a just God to punish sinful Man. Dr. Cogan's Haven of health of 1596 sees the principal cause as "the wrath of God for sin, for so God threateneth, that he will send sickness and disease to those that will not hear His word and disobey His commandments". ${ }^{82}$ As in many similar passages that could be quoted, the possibility of less abstract causation is admitted - stagnant water, corrupt air, astrological conjunctions or overcrowded housing but they are presented as merely the agencies used by God in carrying out His will.

This theological interpretation was accepted so universally that plagues are often referred to as "the visitation of God" or "the visitation". The concept was supported by a range of Old Testament texts, and this in an age newly devoted to personal Bible reading: an example is the text of a plague sermon of 1598-99 — "thou shalt not be purged from thy filthiness till I have caused my wrath to fall upon thee". ${ }^{83}$ Sermons, which were even more popular than usual during epidemics, elaborate upon this simple moral by illustrating the varieties of sin which had provoked the punishment - "filthy drunkenness, abominable whoredoms, open profanation of the sabbath, unlawful pastimes with infinite many more", including "murmuring against God's faithful magistrates or ministers". ${ }^{84}$ The theory provided an opportunity to make sectarian propaganda; under Queen Mary plagues were held to be a result of the protestant policies of the previous reign, while the re-establishment of protestantism under Queen Elizabeth led to the 1563 London plague being blamed on the residual catholicism of the citizens. ${ }^{85}$ Richard Leake blamed "gross popery and

78 Frank P. Wilson (ed.), Plague pamphlets of Thomas Dekker, Oxford, Clarendon Press, 1925, p. 144.

"Thomas F. Thisleton-Dyer, Old English social life, London, 1898, p. 90.

so Cupper, op. cit., note 70 above, p. 106.

31 Bodleian library, Oxford, MS. Gough Eccl. Top. 7.

8s Quoted in Axon, op. cit., note 60 above, p. viii.

Wilson, op. cit., note 68 above, p. 153.

u Ibid., pp. 156, 164.

o6 J. W. Blench, Preaching in England in the fifteenth and sixteenth centuries, Oxford, Blackwell, 1964, p. 280; Millar Maclure, Paul's Cross sermons 1534-1642, Toronto University Press, 1958, p. 205. 
blind superstition" in the backward North while a London preacher in 1636 claimed that "the plague of God was in the land for the new mixture of religion that is commanded in churches". 86 The preacher was given a most powerful weapon in his campaign for moral change, as illustrated in a Paul's Cross sermon of 1577: "the cause of plagues is sin, if you look to it well; and the cause of sin are plays; therefore the cause of plagues are plays". ${ }^{87}$

It was tempting to take the theory one step further and suggest that those who died were receiving personal punishment for their offences. This was encouraged by the obvious fact that cities were the seat of both plague and the conspicuous sins, like drunkenness and prostitution. Some pious but unsubtle Londoners saw the early growth of the 1665 epidemic in the poor and vicious suburbs as confirmation of "the great difference that God did make". ${ }^{88}$ But reflection revealed that the virtuous often died while the vicious continued to enjoy themselves; Cupper devotes a sermon passage bewailing this discovery that "atheists" do not "only live, but to the great admiration and grief many times of God's children, they greatly flourish". ${ }^{80}$ Two explanations were advanced, one the defeatist concept of the inscrutability of God's ways, the other that those who lived through an epidemic without dying suffered more than those who were killed, for "God punisheth not so much those whom he taketh thereby out of this life as those that remain alive. For those that live feel the smart of the plague." 90

The corollary to the thesis of divine punishment was the idea that an epidemic might be averted or ended by religious action, especially repentance. "Only this antidote apply,/Cease vexing Heaven and cease to die". ${ }^{21}$ After the record of the burials from plague, the Nantwich parish register states, "God grant that we by repentance may prevent further punishment and that the remembrance of this plague past may remain in our hearts for that purpose for ever"..$^{22}$ The point could be reached where any religious offence might threaten to bring down vengeance on the offending community - York city council for instance deplored absenteeism from church, for it might "bring God's heavy hand and wrath upon us". ${ }^{93}$ These concepts probably affected the clergy and literate classes most strongly, and there is little evidence of their influence among the lower classes, but at all social levels rational interpretations were surely in part a reflection of an instinctive turning to religion in the face of stress and the likelihood of death.

Religious revivals were a familiar accompaniment to epidemics from the middle ages until the later nineteenth century, but the feelings provoked by the later plagues are of especial significance because they coincide with the development of protes-

\footnotetext{
s6 Wilson, op. cit., note 68 above, pp. 156-172; Philip G. Caraman, Henry Morse, priest of the plague, London, Longman, 1957, p. 93.

87 Blench, op. cit., note 85 above, p. 307.

ss Bell, op. cit., note 4 above, p. 91.

30 Cupper, op. cit., note 70 above, p. 233.

${ }^{\circ}$ Thomas Brasbridge, The poore man's jewel, London, 1578.

-1 Thomas Dekker, Newes from Graves-Ende, London, 1603.

92 Thisleton-Dyer, op. cit., note 79 above, p. 86.

's David M. Palliser, 'Some aspects of the social and economic history of York in the sixteenth century', Oxford D.Phil. thesis, 1968, p. 46.
} 


\section{Alan D. Dyer}

tantism, puritanism, and nonconformity during these years. Plague was by no means the only disease with a religious effect, the chronicler Holinshed, for instance, recording that the sweating sickness of 1551 "enforced the people greatly to call upon God, and to do many deeds of charity". ${ }^{4}$ But plague was much the most influential of the epidemic diseases because, as we have seen, it was much the most disturbing. Many contemporary descriptions testify to the emotional intensity of religious observances during plagues, given official encouragement by the institution of monthly fasts, days of prayer, and special forms of prayer. Even towns uninfected could feel the same effect, for Bristol's fervent prayers for salvation from the spread of the 1625 epidemic were apparently successful, and were felt to be "miraculous in our eyes". .55 Plague was credited with teaching "some religion that never knew what the word meant", ${ }^{96}$ while emotional street processions were said to have halted epidemics; in at least one case the relics of a local saint were said to have been carried through the streets, and this after half a century of nominal protestantism. ${ }^{97}$ The atmosphere is well caught in a description of London in 1665: "If you ever saw a drowning man catch at a rope, you may guess how eagerly many people did catch at the Word, when they were ready to be overwhelmed." 98

There were inevitably limits to the influence of these revivals. As always, they tended to be temporary, and enthusiasts bewailed the back-sliding which soon took place. "Yet when they apprehended the danger to be over, they dropped asleep faster than before: still they are the same or worse than formerly." experience thrust people to the opposite extreme, to the secular rather than the spiritual means of consolation and escape. Alcohol and conviviality were the two chief devices available: "Some streets had churches, full of people, weeping: Some others, taverns had, rude revel keeping". ${ }^{100}$ "In one house you might hear them roaring under the pangs of death, in the next, tippling, whoring and belching out blasphemies against God." 101 Such scenes served to encourage the opposite trend of religious enthusiasm, for were these not prime examples of the sins which were being punished? Thus the effect of plague was to encourage emotional piety, marked by a deep sense of the sinfulness of mankind and its need for either repentance or punishment by a stern and vengeful God. Victims seemed marked out by an inscrutable predestination. These happen to be leading characteristics of the puritan movement which flourished at much the same time as the plague and was, too, an essentially urban phenomenon. The period was marked in any case throughout Europe by a revived religious consciousness, whether catholic or protestant. The relationship between plague and puritanism cannot be a simple one - for instance the concepts of sin, punishment and predestination may well have helped to colour society's reaction to plague as well as vice versa, but at the very least it must be held that the

a Chronicle, sub anno 1551.

${ }^{95}$ Bristol Archives Office, 'William Addames chronicle', sub anno 1625-26.

* Thisleton-Dyer, op. cit., note 79 above, p. 154.

'7 E. M. Leather, Folk-lore of Herefordshire, Hereford, Jakeman \& Carver, 1912, p. 223.

'2 Thomas Vincent, God's terrible voice in the city, 1667, reprinted 1831, p. 51.

"9 Ibid., p. 54.

100 George Wither, History of the pestilence, 1625, quoted in Frank P. Wilson, The plague in Shakespeare's London, Oxford, Clarendon Press, 1927, p. 153.

${ }^{101}$ Bell, op. cit., note 4 above, pp. 222-223. 
similarity between the concepts associated with plague and the basic aspects of plague is too close to be accidental.

On a less theoretical level, plague tended to encourage the spread of nonconformity by discrediting the regular clergy. They tended to join the flight of the rich, so that services were not held, while the hunger for services was at its strongest - in London in 1625 vast crowds came to communion, in an atmosphere in which "few people had thoughts of surviving the contagion". ${ }^{102}$ When, as in Beverley, bodies were "shuffled into graves without any reading over them at all", it is not surprising that the clergy became associated with the absentee upper class. ${ }^{103}$ The predicament was common enough for Richard Baxter to produce in 1665 his Short instructions for the sick, especially who by contagion or otherwise are deprived of the presence of a faithful pastor.

Parishes left untended through death or flight were sometimes taken over unofficially by nonconformists, especially in 1665 when there existed a large stock of recently deprived clerics. ${ }^{104}$ There is evidence too that in earlier London plagues underground Catholic priests made extensive conversions, not least because of their willingness to work in the worst conditions. ${ }^{105}$ In some provincial towns a single puritan stalwart emerges as the sole surviving authority in church and state; John Ivie of Salisbury and Ignatious Jourdain of Exeter are the best examples. Their dogged sense of duty was in part derived from the puritan conviction that life could only be expected to be grim, but it is unlikely that their marked stress on discipline won them many converts. ${ }^{108}$

We have shown the probability of substantial consequences of plague in the economic, social, religious and moral spheres. In most cases the exact extent of the influence of the disease must remain ill-defined, partly because of the absence of any fixed scale by which to measure it, and partly because it tended often to accelerate trends which were already in existence.

One of the most interesting ways of assessing the influence of the disease is to speculate on the results of its disappearance after 1667. It seems to be true that after this date a major discouragement to the growth of big towns was removed, "the pattern began to change and the pace of provincial urban growth accelerated" as the most recent study of town populations in the period puts it. ${ }^{107}$ This is not to suggest that plague had acted as a direct discouragement to population growth, but that the removal of its risks allowed towns to grow to their full potential as social and economic centres. London comes to dominate the nation even more, and can function more continuously as the commercial core of the national economy and as a place of residence and entertainment for a substantial proportion of the upper classes. Most major provincial cities followed London's example, and for the first time many of them became regarded as pleasant residential localities for the landed and pro-

\footnotetext{
102 William Lilly, History of his life and times, London, 1715, p. 18.

108 George Poulson, Beverlac, Beverley, 1829, p. 346.

${ }^{104}$ Bell, op. cit., note 4 above, pp. 223, 228.

${ }^{105}$ Caraman, op. cit., note 86 above.

${ }^{106}$ Slack, op. cit., note 18 above, p. 201; Wallace T. MacCaffrey, Exeter 1540-1640, Cambridge, Mass., Harvard University Press, 1958, p. 234.

${ }^{107}$ Corfield, op. cit., note 5 above, p. 229.
} 
Alan D. Dyer

fessional classes in the years after 1660. At the same time rich traders stopped their automatic exodus to the countryside. This trend served to erode the old distinction between the landed upper class of the country and the monied rulers of the towns, although the new stability of the urban élite inevitably rendered it less open to wealthy newcomers. It must also be acknowledged that the secularism and self-confident optimism of social and intellectual life from the later seventeenth century onwards must owe something to this liberation from the threat of epidemic disaster on its old scale.

\section{SUMMARY}

There are now many studies of specialized aspects of plague, and some useful general surveys, but no extended study devoted to the impact of the disease on the wider life of the community in the early modern period. This essay first examines briefly some of the salient features of plague epidemics which combined to make them unique in their effects and distinguish plague from other epidemic disease of the time. The first of the major aspects dealt with is the demographic role of plague; it is shown to have limited significance as a determinant of population levels nationally, since it was mostly confined to the towns and could not stem the heavy growth in the countryside. But it did help to shape the character of urban populations by influencing the demographic structure and encouraging mobility. In the social and economic sphere plague was much more influential, chiefly through the paralysis of normal life produced by isolation practices and the flight of the rich. This damaged the social fabric at a number of levels and caused extensive economic damage. The disease encouraged the marked religious feeling of the period, and especially nonconformity and puritanism. The disappearance of the disease after 1667 can be associated with the reversal of a number of these factors, including urban growth and secularism. Although attempts are made to quantify where possible, plague's influence is very general, and its effect is often to strengthen existing trends, so that clear-cut conclusions are hard to reach. 